\title{
Tactical Performance of Talented Youth Soccer Players Rendimiento táctico de jóvenes jugadores de fútbol con talento
}

\author{
${ }^{1}$ Facultad de Educación de Cuenca. Universidad de Castilla-La Mancha, España \\ ${ }^{2}$ Facultad de Educación de Albacete. Universidad de Castilla-La Mancha, España \\ ${ }^{3}$ Facultad de Educación de Toledo. Universidad de Castilla-La Mancha, España \\ * Correspondence: Email: Jesús.Mmartinez@uclm.es. Teléfono: 926051600. \\ Dirección postal: Facultad de Educación. Avenida Carlos III s/n. Toledo (Toledo). \\ 45071.
}

Alejandro Prieto-Ayuso ${ }^{1}$, Juan Carlos Pastor-Vicedo ${ }^{2}$, Jesús Martínez-Martínez ${ }^{3 *}$, Onofre Ricardo Contreras-Jordán ${ }^{2}$
Received: 19 March 2021 / Accepted: 22 December 2021
HOW TO CITE THIS ARTICLE:

Prieto-Ayuso, A., Pastor-Vicedo, J. C., Martínez-Martínez, J., \& Contreras-Jordán, O. R. (2022). Tactical Performance of Talented Youth Soccer Players. Cultura, Ciencia y Deporte, 17(51), 145-152. http://dx.doi.org/10.12800/ccd.v17i51.1721

\section{Abstract}

The evaluation of talented soccer players has been based, traditionally, on physical capacities through technical-tactical tests. However, in the last years, soccer academies are focused their evaluations on technical-tactical and physical capacities, as well. Given that, the purpose of this work has been twofold: 1) to examine the evolution of the tactical performance of a group of talented players previously selected; 2 ) to compare the tactical performance between talented and non-talented players in previous literature. A total of 607 tactical sequences were evaluated. A total of 15 players were selected from an initial sample of 104 soccer players aged 14-23 years $(17.03 \pm 2.01)$. The Nomination Scale for identifying Football Talent and the FUT-SAT instrument were used. The results indicated that the tactical principle Width and Length are the most used in the offensive phase, while Defensive Unity is the most frequent in the defensive phase. The effectiveness of the tactical principles decreases from $\mathrm{U}-16$ to $\mathrm{U}-23$. Finally, there is a greater percentage of efficacy in the use of tactical principles with talented players. In summary, that talented soccer players may have a better tactical acquisition in the offensive phase than the defensive. So, the precocity in tactical acquisition of these players must be considered when designing training sessions.

Keywords: sport initiation, gifted, education, decisionmaking, invasion game.

\section{Resumen}

La evaluación de los futbolistas talentosos se ha basado en pruebas técnicas aisladas. El lado táctico de cada jugador de fútbol ahora ha ganado más importancia. Por eso, el propósito de este trabajo ha sido doble. Primero, examinar la evolución del desempeño táctico de un grupo de jugadores talentosos previamente seleccionados. En segundo lugar, comparar el desempeño táctico entre jugadores talentosos y no talentosos. Se evaluaron un total de 607 secuencias tácticas. Estos jugadores fueron seleccionados de una muestra inicial de 104 jugadores de fútbol con edades comprendidas entre 14 y 23 años (17.03 \pm 2.01$)$. Se utilizó la Escala de Nominación para la identificación del Talento del Fútbol y el instrumento FUTSAT. Los resultados indicaron que el principio táctico amplitud y longitud son los más utilizados en la fase ofensiva, mientras que unidad defensiva es el más frecuente en la fase defensiva. La efectividad de los principios tácticos disminuye de U-16 a U-23. Existe un mayor porcentaje de eficacia en el uso de principios tácticos con jugadores talentosos. Se concluye que los futbolistas talentosos tienen una mejor adquisición táctica en la fase ofensiva que en la defensiva. Por tanto, la precocidad en la adquisición táctica de estos jugadores debe tenerse en cuenta a la hora de diseñar las sesiones de entrenamiento.

Palabras clave: iniciación deportiva, superdotados, educación, toma de decisiones, deporte de invasión. 


\section{Introduction}

The evaluation of performance in talented players has been a matter of great interest in the last decade, increasingly in the topic in sports (Morley et al., 2017) and specifically in soccer (Pankhurst \& Collins, 2013). Recent studies claim that the current selection processes must move the evaluation of talented soccer players towards new trends (Penney \& McMahon, 2016) focusing on the tactical side of the player (Baker et al., 2017), replacing isolated tests (Serra-Olivares et al., 2016), which have no relevance when reaching the elite level (Nicolairé et al., 2013).

Regarding sporting initiation (from 8 to 14 years old), there are several instruments designed to evaluate the tactical performance of the young player (González-Víllora et al., 2015) such as the Game Performance Evaluation Tool, Performance Assessment in Team Sport and Game Performance Assessment Instrument. Thus, examples of how decision-making (DM) evolves has been studied in invasion games (Sanchez-Mora et al., 2011) such as volleyball (Araújo et al., 2015) and soccer (Praxedes et al., 2018), in which focus has even been given specifically to goalkeepers (Lamas et al., 2018). In short, it can be concluded that DM is the key characteristic that determines the trajectory of an athlete.

However, despite the enormous amount of money that soccer clubs are willing to invest in soccer players, experts do not count using these kinds of instruments from the youth age group onwards, or their reliability has been questioned (Ali, 2011; Forsman et al., 2016). On the one hand, performance indicators are being used to evaluate both soccer players and teams (Liu et al., 2015; Rein \& Memmert, 2016; Sarmento et al., 2017). On the other hand, the insight of scouters is also considered a good way to make decisions when selecting young soccer players (Holt, 2002). Finally, classical tests are often used to evaluate technical, physiological or psychological aspects of soccer players (Murr et al., 2017; Phillips et al., 2010). Nevertheless, all these tests have limitations regarding their incapacity to measure DM (Santos et al., 2017), which can lead to biases regarding the relative age effect (Chittle et al., 2018; Gadžić et al., 2017; Gutierrez et al., 2010), maturation and physical condition (Towlson et al., 2017). It is necessary to take into account instruments such as TacticUp (Machado \& Teoldo, 2019), an online evaluation platform that allows us to objectively determine soccer players' reading ability of the game and DM.

In this direction, the System of Tactical Assessment in Soccer (FUT-SAT) (Costa et al., 2011) can be a starting point for an improved evaluation of soccer players from 14 years old onwards, considering the importance of the tactical side of the player (Badari et al., 2021; Machado et al.,
2019). In the last five years, some studies have used FUTSAT with the purpose of understanding the DM in players of different ages. For example, Rechenchosky et al. (2017) analyzed the effectiveness of tactical principles in an U15 group, comparing them among the different game positions (defender, midfielder and striker). Correia et al. (2019) compared the quantity, quality and result of tactical actions in the U15 age group among professional and amateur soccer teams. Small-side games were used, and the results showed that professional players performed longer offensive tactical actions. Rodrigues et al. (2019) found in the U15 age group that soccer players with better tactical performance respond quicker to game demands. Bueno, Figueiredo and Costa (2013) compared the tactical performance between U11 and U17 players, finding that U17 players carried out more actions in nine of the ten principles that this tool evaluates. Figueiredo et al. (2013) analyzed tactical behavior, finding that U13 players exhibited better performance in four offensive tactical principles and four defensive tactical principles than U11 players. Brito et al. (2015) compared the performance of U14 and U15 players, finding that U15 players were able to protect the most dangerous areas of the field.

While there have been a number of studies looking at differences among lower age groups (González-Víllora et al., 2015; Praxedes et al., 2018), no study has been found the differences among talented and non-talented players in higher categories, which makes it difficult to conduct a suitable transition from youth soccer to senior soccer (Christensen \& Sorensen, 2009; Roynesdal et al., 2018). Moreover, this process is based mainly on expert opinion instead of scientific evidence (Woods et al., 2016). Given that, the purpose of this work has been twofold: 1) to examine the evolution of the tactical performance of a group of talented players previously selected (U16, U18 and U23); 2) to compare the tactical performance between talented and non-talented players in previous literature.

\section{Methods}

\section{Participants}

A total of 607 tactical sequences were evaluated from 15 talented youth soccer players. These players were selected from an initial sample of 104 soccer players $\left(M_{\text {age }}=17.03\right.$, $S D_{\text {age }}=2.01 ; M_{\text {weight }}=65.38 \mathrm{~kg}, S D_{\text {weight }}=6.81 \mathrm{~kg} ; M_{\text {height }}=$ $175 \mathrm{~cm}, S D_{\text {height }}=6.55 \mathrm{~cm}$ ) aged $14-23$ years. They belonged to the soccer academy of a professional club. The U16 and U18 age group had the same amount of training: Four weekly sessions of 90 mins each; meanwhile, the U23 age group had five weekly sessions. Those players who were injured were not considered in this study. The table 1 shows the microcycle of the participants. 
Table 1. Microcycle of the participants

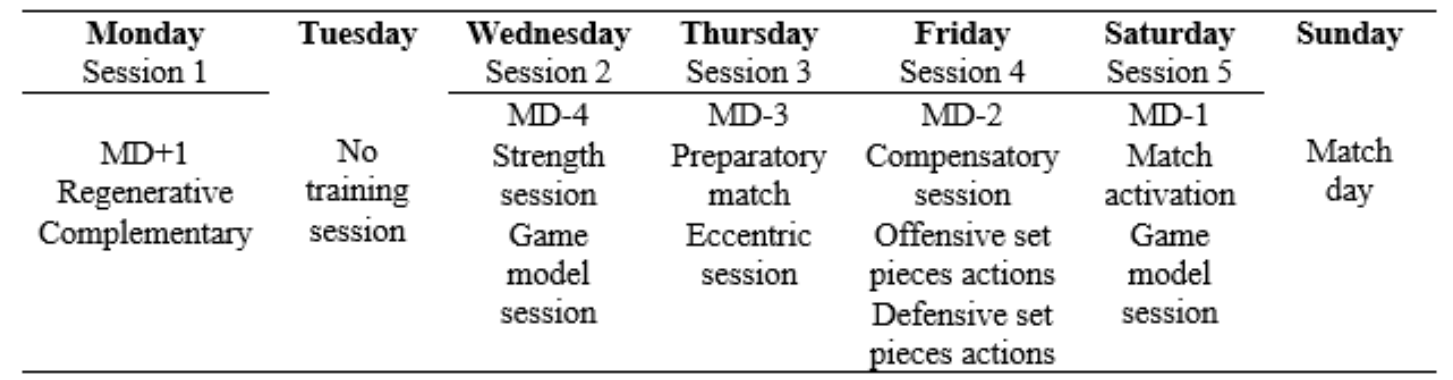

Notes: MD = Match Day

As the sample was mostly composed of underage children, parents gave their consent for their children to participate in the study, while children also gave their verbal approval prior to data collection. The research project was fully approved by the Ethical Committee of the University of Castilla-La Mancha. The research has been developed under the recommendations of the Declaration of Helsinki.

Instruments

The Nomination Scale for Identifying Football Talent (NSIFT) helped to select those talented players through the evaluation of three dimensions: (1) cognitive aspects, relating to game intelligence and problem solving; (2) psychological aspects, relating to sport commitment and the ability to shoulder responsibilities; and (3) motivation, relating to the desire to improve as a player. It was recently designed and validated by Prieto-Ayuso et al. (2017).

Coaches, parents and teammates took part in the validation process. These three groups had a good correspondence with the final selection. Parents exhibited a moderate correlation with the selection (0.499), coaches showed a high correlation (0.711), and teammates showed a very high correlation $(0.847)$. Finally, the scale had a reliability result of 0.88

Once these players were selected, FUT-SAT (Costa et al., 2011) was used for tactical performance analysis. This instrument was designed to determine the tactical behavior of soccer players from 13-14 years old onwards. It is based on ten fundamental tactical principles in soccer, influenced by both spatial and temporal parameters of the game. We considered tactical principles (Penetration, Offensive coverage, Depth Mobility, Width and Length, and Offensive Unity), place of action (Offensive or Defensive side), and action outcomes (Keep or Lose the ball).

The test-retest method has been used to verify the reliability of the observations in FUT-SAT, maintaining an interval of three weeks between both tests to avoid problems of familiarity with the task (Robinson \& O'Donoghue, 2007). Three evaluators that were based on the criteria of the "Observational criteria of FUT-SAT", which facilitates the analysis, evaluation and classification of the tactical actions carried out by the players who participated in the procedure.

\section{Procedure}

This was a descriptive design with two groups, carried out in two phases: (1) the selection process, in which the talented players were discriminated with the NSIFT; and (2) performance analysis, when the data collection was carried out through the recording of matches in the three groups. This took place in the last two months of the regular season. They were carried out over five days, one for each team analyzed. A random match of the regular season (11 vs 11) was recorded with a Sony HDR-AS100VR camera, located in the highest part of the stadium and recording the entire field, with the purpose to facilitate player analysis. A full match was recorded (90 minutes) but only the first ten minutes were analyzed, according to the indications of the authors (García-López et al., 2013).

\section{Statistical Analysis}

To conduct the statistical analysis, $10 \%$ of the sample were reevaluated, a value equal to that indicated by previous studies (Tabchnick \& Fidell, 2007). The values for intra-observer reliability indicated a minimum of 0.813 and maximum of 1000. The inter-observer reliability presented a minimum of 0.813 and maximum of 1000 . SPSS v.22.0. software was used to process the data. For descriptive analysis, frequencies, means, standard deviations and percentages of success of the tactical actions were used. For the inferential analysis, the Kolmogorov-Smirnov test confirmed a normal distribution of variables, leading to the use of parametric tests. The Kappa de Cohen statistic was used to calculate the reliability. To check the tactical performance differences among the three groups, a one-way ANOVA with Bonferroni post-hoc test was applied, the purpose being to know the differences between each pair age group. Finally, a correlational analysis (Rho Pearson) was used to understand the relationship between the Tactical Performance Index (TPI) and the three groups analyzed. A difference was considered significant with a p-value of $<0.05$.

\section{Results}

On the one hand, the Table 2 presents the frequency and percentage of success for the tactical principles of talented soccer players in each sequence. The descriptive analysis demonstrates a high efficiency in tactical principles, with effectiveness between $50 \%$ and $100 \%$. On the other hand, both frequency and effectiveness tend to decrease as the age group advances. Of all groups analyzed, the most common 
behavior in the offensive phase was Width and Length, and in the defensive phase, this was Defensive Unity. In relation to the inferential analysis, only the tactical principle Defensive
Unity $(p=0.003)$, as well as Total Defensive $(p=0.000)$, showed significant difference.

Table 2. Frequency of actions percentage of success $\%$ and significant differences $p$ in tactical principles ANOVA in each sequence

\begin{tabular}{lcccc}
\hline & $\mathbf{U}-16$ & $\mathbf{U}-18$ & $\mathbf{U}-23$ & \\
\hline & $\mathrm{N}(\%)$ & $\mathrm{N}(\%)$ & $\mathrm{N}(\%)$ & $p$ \\
Penetration & & & & \\
Offensive coverage & $34(100 \%)$ & $2(50 \%)$ & $4(100 \%)$ & .092 \\
Depth mobility & $1(100 \%)$ & $20(100 \%)$ & $36(96.82 \%)$ & .162 \\
Width and Length & $131(97.40 \%)$ & $127(93.22 \%)$ & $123(97.26 \%)$ & .450 \\
Offensive Unity & $123(100 \%)$ & $100(100 \%)$ & $31(100 \%)$ & - \\
& & & & \\
Delay & $13(100 \%)$ & $1894.44 \%)$ & $1(100 \%)$ & .600 \\
Defensive Coverage & $10(100 \%)$ & $22(100 \%)$ & $2(50 \%)$ & - \\
Balance & $22(100 \%)$ & $21(100 \%)$ & $5(91.66)$ & .133 \\
Concentration & $38(100 \%)$ & $28(100 \%)$ & $5(100 \%)$ & - \\
Defensive Unity & $56(100 \%)$ & $156(100 \%)$ & $39(97.60 \%)$ & $.003 *$ \\
& & & & \\
Total Tactical Offensive & $299(98.55 \%)$ & $249(96.92 \%)$ & $206(97.60 \%)$ & .451 \\
Total Tactical Defensive & $139(100 \%)$ & $245(99.30 \%)$ & $52(89.47 \%)$ & $.000^{* *}$ \\
Total Sequences & $230(37.89 \%)$ & $250(41.18 \%)$ & $127(20.93 \%)$ & \\
\hline
\end{tabular}

Notes: Total offensive $=\sum$ offensive tactical actions; total defensive $=\sum$ defensive tactical total; ${ }^{*} p<0.05 ;{ }^{*} p<0.001$

Then, a post-hoc Bonferroni test was used. Table 3 shows that there was a significant difference in the Defensive Unity principle among the age group pairs of $\mathrm{U} 16$ and $\mathrm{U} 23$, and $\mathrm{U} 18$ and U23. Furthermore, the Total Defensive principle showed significant differences between all three groups.

Table 3. Mean differences between each pair of age groups (Bonferroni test).

\begin{tabular}{lcc}
\hline & Pairs & $p$ \\
\hline \multirow{2}{*}{ Defensive unity } & $\mathrm{U}-16$ and U-23 & $.006^{*}$ \\
& $\mathrm{U}-18$ and U-23 & $.006^{*}$ \\
& & \\
& $\mathrm{U}-16$ and U-18 & $.000^{*}$ \\
Total defensive & $\mathrm{U}-18$ and U-23 & $.000^{*}$ \\
& $\mathrm{U}-16$ and U-23 & $.000^{*}$ \\
\hline
\end{tabular}

Notes: ${ }^{*} \mathrm{p}<0.05$

Table 4 presents the relationship between the TPI of each of the tactical principles analyzed and the age group. It was observed that Penetration, Offensive Coverage, Width and Length, and Concentration, had a positive relationship with age group. In contrast with the previous results, Depth
Mobility, Offensive Unity, Delay, Defensive Coverage, Balance and Offensive Unity all showed negative correlations with age group. These relationships were significant for Offensive Unity, Width and Length, Balance and Defensive Unity. 
Table 4. Correlation analysis between tactical principles and age groups (Rho Pearson)

\begin{tabular}{lcc}
\hline & $\boldsymbol{r}$ & $\boldsymbol{p}$ \\
\hline Penetration & .359 & .278 \\
Offensive Coverage & .622 & $.017^{*}$ \\
Depth Mobility & -.857 & .344 \\
Width and Length & .726 & $.002^{*}$ \\
Offensive Unity & -.243 & .384 \\
Delay & -.090 & .771 \\
Defensive Coverage & -.498 & .119 \\
Balance & -.532 & $.041^{*}$ \\
Concentration & .175 & .533 \\
Defensive Unity & -.609 & $.016^{*}$ \\
\hline
\end{tabular}

Notes: $r=$ correlation coefficient; ${ }^{*}$ ) statistically significant correlation $={ }^{*} p<0.05 ;{ }^{* *} p<0.001$

Table 5 reflects the relationships that marked a significant association between the principles evaluated.

Table 5. Significant relationships between tactical principles (Pearson Rho).

\begin{tabular}{lll}
\hline & $r$ & \multicolumn{1}{c}{$p$} \\
\hline Width and Length - Penetration & .615 & $.044^{*}$ \\
Width and Length - Offensive Coverage & .865 & $.000^{* *}$ \\
Delay - Depth Mobility & .1000 & $.000^{* *}$ \\
Width and Length - Balance & -.579 & $.024^{*}$ \\
Delay - Concentration & .823 & $.001^{* *}$ \\
\hline
\end{tabular}

Notes: $r=$ correlation coefficient; ${ }^{*} \mathrm{p}<0.05 ;{ }^{*} \mathrm{p}<0.001$

\section{Discussion}

The objectives of the study were to understand the tactical performance in a group of soccer players selected as talented (U16, U18 and U23) and to compare game performance between talented and non-talented players. The results showed that 15 players were nominated as talented. To our knowledge, no previous study whose objectives were to evaluate game performance in soccer players in these age groups has adopted a selection process as objective as is presented here. For example, Sánchez-Mora et al. (2011) divided the sample into teams of a similar level of skillfulness, without showing the protocol used. Hastie et al. (2011) used a participation requirement in which players had to have attended three tests of physical condition and six practice sessions. In the study of Araújo et al. (2015), the participants had no previous experience. Práxedes et al. (2018) divided the sample into average skill-level and low skill-level, according to the team level of each participant. However, despite the existence of studies aiming to understand the tactical performance of soccer players (Lamas et al., 2018; Liu et al., 2015), this study has chosen a sample based on a rigorous selection process using the NSIFT.
The results of talented soccer players indicated that the tactical principle Width and Length is mostly performed in the offensive phase, while Defensive Unity is the most frequent tactical principle adopted in the defensive phase. These results coincide with the results of Bueno et al. (2013), in which both principles were the most used by the players. In the offensive phase, the soccer players used to perform a greater number of actions without the ball in defense line of the ball, with the intention of creating a pass line. During the defense, more actions are also performed outside of the center of the game, with the purpose of protecting the goal or being well positioned to defend the rival's attack.

Previous studies, such as those conducted by Bueno et al. (2013) and Figueiredo et al. (2013) indicated significant differences in the comparison of tactical performance in the Defensive Unity principle. This difference among U11, U13 and U17 age groups was also found in this study among the U18 and U23 groups. This could indicate that while the players have assimilated those concepts related to offense from U16 level, this is not the same for the defensive side. There are differences in tactical performance as the age group progresses. In addition, the individual style of play can influence these results. The club in which the investigation was applied bases its game model on attacking, which

Cultura, Ciencia y Deporte $\mid$ AÑo 2022 | volumeN 17 | NUM. 51 | España | PÁG. 145 A 152 | ISSN: 1696-5043 
may explain why the players assimilated offensive tactical principles earlier than defensive ones.

The effectiveness of the tactical principles decreases slightly from U16 to U23. This result might be caused by the lack of an adequate talent development model in the literature reviewed (Sarmento et al., 2018). According to the pyramidal model (Bailey \& Collins, 2013) the promotion into phases is based on age instead of performance. Moreover, the reliability of the instruments designed for the evaluation of the talented soccer players have not been proved (Nicolairé et al., 2013), even at elite level (Forsman et al., 2016). Bearing that in mind, the development of expertise might be influenced by both physical and maturation biases (Towlson et al., 2017), due to the well-known problem of relative age effect (Chittle et al., 2018) in the selection processes. New trends are emerging when it comes to evaluating talented soccer players (Sarmento et al., 2017). Unlike the classical test performed in isolated laboratory situations (Serra-Olivares et al., 2016), ecological processes are being considered (Sanchez-Mora et al., 2011; Araújo et al., 2017). The validation of the NSIFT (Prieto-Ayuso et al., 2017) has been a first step in the current evaluation of talented soccer players, including not only cognitive aspects related to game performance, but also both psychological and social aspects.

Regarding the second aim, it has been shown that there is a greater percentage of efficacy in the use of tactical principles through FUT-SAT, when comparing these results with a nontalented sample of players. For instance, Silva, Garganta, Santos and Teoldo (2014) found percentages of success in tactical principles of between $3 \%$ and $33 \%$; the results of Bueno et al. (2013) were between 65\% and 94\%; and the results of Figueiredo et al. (2013) were between 25\% and 99\%. Nevertheless, the results presented with a sample previously selected as talented showed an effectiveness of between $50 \%$ and $100 \%$, which is higher than previous studies.

Therefore, it is once again shown that talented players learn tactical principles earlier than their peers do. In addition, the higher effectiveness in older age groups shows the importance of deliberate practice (Ford et al., 2012) in the pathway to expertise. This has also been proved with the Tactical Performance Index. The results revealed a better TPI in older age groups in Penetration, Offensive Coverage, Width and Length, and Concentration compared with previous studies (Correia et al., 2019; Rechenchosky et al., 2017). However, Depth Mobility, Offensive Unity, Delay, Defensive Coverage, Balance and Defensive Unity exhibited lower values in older age groups. This could be explained by the fact that the soccer team in which the research was carried out focused its playing style on offense instead of defense, meaning soccer players will develop more skills in the attacking rather than the defensive side of the game. Special attention should be given to Balance and Defensive Unity, as they showed a negative relationship. These results should be taken into account by coaches, bearing in mind that the improvement of one tactical principle can positively affect another (e.g., Delay and Concentration).

The findings of this work can lead us to consider some practical applications not only for coaches but also for Physical Education teachers (Houlihan, 2000). Due to the fact that the high tactical performance shown by those players nominated as talented, it is necessary to put into practice a specific program for those players from a young age. This is common practice in other subjects (Hornstra et al., 2017; Wilkinson et al., 2015), but does not seem common in the soccer context. Thus, modified games (Kirk \& Gorely, 2000), teaching games for understanding (Light \& Tan, 2006) and futsal (Travassos et al., 2018; Yiannaki et al., 2018) could be good starting points in order to improve the tactical side of these soccer players. Moreover, the work has been carried out in males, but it is necessary to know the results for females as well, in order to improve physical activity and participation in sport (Gutierrez \& Garcia-Lopez, 2015; Kirk, 2005; Young et al., 2015).

Finally, despite the strengths that this study presents, it is necessary to bring to light two limitations. First, the small number of participants who participated in the study. However, it is a common limitation in the studies with talented people, due to the number of talented people is only the $10 \%$ of a normal population. Secondly, we only studied male soccer players. Future studies must consider female samples in their objectives.

\section{Conclusions}

After carrying out the tactical evaluation of a group of talented soccer players, it was possible to come to the following conclusions. First, from a general point of view, talented soccer players show a better tactical acquisition in the offensive phase than the defensive phase. Secondly, talented players should be offered an individualized teaching program due to the fact they have exhibited greater tactical effectiveness in comparison with those non-detected for talent players in previous studies. Therefore, the precocity in tactical acquisition of these players must be considered by coaches in their training sessions.

\section{References}

Ali, A. (2011). Measuring soccer skill performance: a review. Scandinavian journal of medicine \& science in sports, 21(2), 170-183. http://dx.doi.org/10.1111/j.1600-0838.2010.0125 6.x

Araújo, D., Hristovski, R., Seifert, L., Carvalho, J., \& Davids, K. (2017). Ecological cognition: expert decision-making behaviour in sport. International Review of Sport and Exercise Psychology, 1-25. http://dx.doi.org/10.1080/1750984X.2017 .1349826

Araújo, R., Mesquita, I., Hastie, P., \& Pereira, C. (2016). Students' game performance improvements during a hybrid sport education-step-game-approach volleyball unit. European Physical Education Review, 22(2), 185-200. htt p://dx.doi.org/10.1177/1356336X15597927

Badari, T. P., Machado, G., Moniz, F., Fontes, A., \& Teoldo, I. (2021). Comparison of soccer players' tactical behaviour in small-sided games according to match status. Journal of Physical Education and Sport, 21(1), 12-20. http://dx.doi.org /10.7752/jpes.2021.01002

Bailey, R. \& Collins, D. (2013). The standard model of talent development and its discontents. Kinesiology Review, 2(4), 248-259. http://dx.doi.org/10.1123/krj.2.4.248

Brito, R., De Oliveira, V., Moreira, G., Julio, C., Da Costa, I. T., \& Juan, P. (2015). Avaliaçao do comportamento tático no futebol: Princípios táticos fundamentais nas categorias Sub-14 e Sub-15 Revista Brasileira de Ciência e Movimento, 23(2), 59-65. http://dx.doi.org/10.18511/0103-1716/rbcm. v23n2p59-65

Bueno, H., Figueiredo, G., \& Costa, I. T. (2013). Comparação do comportamento tático de jogadores de futebol entre 
categorias sub-11 e sub-17. Revista Mineira de Educação Física, 715-721.

Baker, J., Schorer, J., \& Wattie, N. (2017). Compromising talent: issues in identifying and selecting talent in sport. Quest, 1-16. http://dx.doi.org/10.1080/00336297.2017.1333438

Chittle, L., Horton, S., \& Dixon, J. C. (2018). Relative age effects and academic timing in Canadian interuniversity football. High Ability Studies. 1-14. http://dx.doi.org/10.1080/135981 39.2017.1423042

Costa, I., Garganta, J., Greco, P., Mesquita, I., \& Maia, J. (2011). System of tactical assessment in Soccer (FUT-SAT): Development and preliminary validation. Motricidade, 7(1), 69-83. http://dx.doi.org/10.6063/motricidade.7(1).121

Correia, D., Teoldo, V., Casanova, F., Clemente, F. M., \& Teoldo, I. (2019). Comparison between teams of different ranks in small-sided and conditioned games tournaments, International Journal of Performance Analysis in Sport, 19(4), 608-623, http://dx.doi.org/10.1080/24748668.2019.164359 8

Christensen, M. K., \& Sorensen, J. K. (2009). Sport or school? Dreams and dilemmas for talented young Danish football players. European Physical Education Review, 15(1), 115-133. http://dx.doi.org/10.1177/1356336X09105214

Figueiredo, G., Gonçalves, E., \& Costa, I. T. (2013). Comparação entre o comportamento tático de jogadores de futebol das categorias sub-11 e sub-13. Revista Mineira de Educacao Fisica (UFV), 9, 701-707.

Ford, P. R., Carling, C., Garces, M., Marques, M., Miguel, C., Farrant, A., \& Salmela, J. H. (2012). The developmental activities of elite soccer players aged under-16 years from Brazil, England, France, Ghana, Mexico, Portugal and Sweden. Journal of sports sciences, 30(15), 1653-1663. http: //dx.doi.org/10.1080/02640414.2012.701762

Forsman, H., Blomqvist, M., Davids, K., Liukkonen, J., \& Konttinen, N. (2016). Identifying technical, physiological, tactical and psychological characteristics that contribute to career progression in soccer. International journal of Sports Science \& Coaching, 11(4), 505-513. http://dx.doi.org/10.117 7/1747954116655051

Gadžić, A., Milojević, A., Stanković, V., \& Vučković, I. (2017). Relative age effects on motor performance of seventhgrade pupils. European Physical Education Review, 23(4), 534-542. http://dx.doi.org/10.1177/1356336X16671696

García-López, L. M., González-Víllora, S., Gutiérrez, D., \& Serra, J. (2013). Development and validation of the Game Performance Evaluation Tool (GPET) in soccer. Sport TK: Revista Euroamericana de Ciencias del Deporte, 2(1), 89-99.

González-Víllora, S., García-López, L. M., \& Contreras-Jordán, O. R. (2015). Decision Making and Technical Skills Evolution in Football. International Journal of Medicine and Science of Physical Activity and Sport, 59, 467-487. http://dx.doi.org/10 .15366/rimcafd2015.59.005

González-Víllora, S., Serra-Olivares, J., Pastor-Vicedo, J. C., \& Costa, I. T. (2015). Review of the tactical evaluation tools for youth players, assessing the tactics in team sports: football. SpringerPlus, 4(1), 663. http://dx.doi.org/10.1186/s40064-0 15-1462-0

Gutierrez, D., \& Garcia-Lopez, L. M. (2012). Gender differences in game behaviour in invasion games. Physical Education \& Sport Pedagogy, 17(3), 289-301. http://dx.doi.org/10.1080/1 7408989.2012.690379

Gutierrez, D., Pastor-Vicedo, J.C., Gonzalez-Villora, S. \& Contreras-Jordan, C. (2010). The relative age effect in youth soccer players from Spain. Journal of Sports Science and Medicine, 9(2), 190-198.

Hastie, P.A., Calderón, A., Palao, J. \& Ortega. E. (2011). Quantity and quality of practice: Interrelationships between task organization and student skill level in physical education. Research Quarterly for Exercise and Sport, 82(4), 784-787. htt p://dx.doi.org/10.1080/02701367.2011.10599815

Holt, N. L. (2002). A comparison of the soccer talent development systems in England and Canada. European Physical Education Review, 8(3), 270-285. http://dx.doi.org/1 $0.1177 / 1356336 \times 020083006$

Hornstra, L., Van der Veen, I., \& Peetsma, T. (2017). Effects of full-time and part-time high-ability programs on developments in students' achievement emotions. High Ability Studies, 28(2), 199-224. http://dx.doi.org/10.1080/13 598139.2017.1332575

Houlihan, B. (2000). Sporting excellence, schools and sports development: The politics of crowded policy spaces. European physical education review, 6(2), 171-193. http://dx. doi.org/10.1177/1356336X000062005

Kirk, D. (2005). Physical education, youth sport and lifelong participation: the importance of early learning experiences. European Physical Education Review, 11(3), 239-255. http://d x.doi.org/10.1177/1356336X05056649

Kirk, D., \& Gorely, T. (2000). Challenging thinking about the relationship between school physical education and sport performance. European Physical Education Review, 6(2), 119-134. http://dx.doi.org/10.1177/1356336X0000620 02

Lamas, L., Drezner, R., Otranto, G., \& Barrera, J. (2018). Analytic method for evaluating players' decisions in team sports: Applications to the soccer goalkeeper. PloS One, 13(2), e0191431. http://dx.doi.org/10.1371/journal.pone.019143 1

Light, R., \& Tan, S. (2006). Culture, embodied experience and teachers' development of TGfU in Australia and Singapore. European Physical Education Review, 12(1), 99-117. http://dx .doi.org/10.1177/1356336X06060659

Liu, H., Gomez, M. Á., Lago-Peñas, C., \& Sampaio, J. (2015). Match statistics related to winning in the group stage of 2014 Brazil FIFA World Cup. Journal of Sports Sciences, 33(12), 1205-1213. http://dx.doi.org/10.1080/02640414.20 15.1022578

Machado, G., Bach, M., González, S., Clemente, F. M., \& Teoldo, I. (2019). The effects of positional role on tactical behaviour in a four-a-side small-sided and conditioning soccer game. Kinesiology, 51(2.), 261-270. http://dx.doi.org/10.26582/k.51 .2 .15

Machado, G. \& Teoldo, I, (2019). TacticUP: Validação de construto de um teste para avaliação do conhecimento tático declarativo de jogadores de futebol. Anais $7^{\circ} \mathrm{Soccer}$ Experience - Tática. Revista Brasileira de Futebol, ISSN: 1983-7194

Morley, D., McKenna, J., Gilbert, S., French, J., Till, K., Quarmby, T., \& Turner, G. (2017). Can't pay, can't play? Talent lead's perspectives on the financial constraints experienced by athletes on the England Talent Pathway. High Ability Studies, 1-14. http://dx.doi.org/10.1080/13598139.2017.1341389

Murr, D., Raabe, J., \& Höner, O. (2018). The prognostic value of physiological and physical characteristics in youth soccer: A systematic review. European journal of sport science, 18(1), 62-74. http://dx.doi.org/10.1080/17461391.2017.1386719

Cultura, Ciencia y Deporte | AÑo 2022 | volumen 17 | NUM. 51 | España | PÁG. 145 A 152 | ISSN: 1696-5043 
Nicolairé, A. H., Cattuzzo, M. T., \& De Mello, C. B. (2013). Questionable use of performance testing to predict success in soccer players: comment on Ljach, et al. (2012). Perceptual and Motor Skills, 116(1), 352-354. http://dx.doi.o rg/10.2466/30.10.25.PMS.116.1.352-354

Pankhurst, A., \& Collins, D. (2013). Talent identification and development: The need for coherence between research, system, and process. Quest, 65(1), 83-97. http://dx.doi.org/ 10.1080/00336297.2012.727374

Penney, D., \& McMahon, J. (2016). High-performance sport, learning and culture: new horizons for sport pedagogues?. Physical Education and Sport Pedagogy, 21(1), 81-88. http://d x.doi.org/10.1080/17408989.2015.1072511

Phillips, E., Davids, K., Renshaw, I., \& Portus, M. (2010). Expert performance in sport and the dynamics of talent development. Sports medicine, 40(4), 271-283. http://dx.doi .org/10.2165/11319430-000000000-00000

Práxedes, A., Moreno, A., Gil-Arias, A., Claver, F., \& Del Villar, F. (2018). The effect of small-sided games with different levels of opposition on the tactical behaviour of young footballers with different levels of sport expertise. PloS One, 13(1), e0190157. http://dx.doi.org/10.1371/journal.pone.0 190157.

Prieto-Ayuso, A., Pastor-Vicedo, J. C., \& Contreras-Jordán, O. (2017). Content validity and psychometric properties of the nomination scale for identifying football talent (NSIFT): Application to coaches, parents and players. Sports, 5(1), 2. http://dx.doi.org/10.3390/sports5010002

Rein, R., \& Memmert, D. (2016). Big data and tactical analysis in elite soccer: future challenges and opportunities for sports science. SpringerPlus, 5(1), 1410. http://dx.doi.org/10.1186/ s40064-016-3108-2

Rechenchosky, L., Borges, PH., Menegassi, VM., de Oliveira, JM., Guilherme, J., Teoldo, I., \& Rinaldi, W. (2017). Comparison of tactical principles efficiency among soccer players from different game positions. Human Movement, 18(5) special/issue:31-38; doi: 10.1515/humo-2017-0040

Rodrigues, M., dos Santos, A., Greco, PJ., \& Teoldo I. (2019). Association between inhibitory control and tactical performance of under-15 soccer players. Journal of Sport Psychology, 28 (1). 63-70.

Robinson, G., \& O'Donoghue, P. (2007). A weighted kappa statistic for reliability testing in performance analysis of sport. International Journal of Performance Analysis in Sport. 7(1), 12-19. http://dx.doi.org/10.1080/24748668.2007.1186 8383

Røynesdal, Ø., Toering, T., \& Gustafsson, H. (2018). Understanding players' transition from youth to senior professional football environments: A coach perspective. International Journal of Sports Science \& Coaching, 13(1), 26-37. http://dx.doi.org/10.1177/1747954117746497

Sanchez-Mora, D., García, L. M., Del Valle, M., \& Solera, I. (2011). Spanish primary school students' knowledge of invasion games. Physical Education \& Sport Pedagogy. 16(3), 251-264. http://dx.doi.org/10.1080/17408989.2010.5 35195

Santos, S., Jiménez, S., Sampaio, J., \& Leite, N. (2017). Effects of the Skills4Genius sports-based training program in creative behavior. PloS One, 12(2), e0172520. http://dx.doi.org/10.1 371/journal.pone.0172520

Sarmento, H., Anguera, M. T., Pereira, A., \& Araújo, D. (2018). Talent Identification and Development in Male Football: $\mathrm{A}$
Systematic Review. Sports Medicine, 1-25. http://dx.doi.org/ 10.1007/s40279-017-0851-7

Sarmento, H., Clemente, F. M., Araújo, D., Davids, K., McRobert, A., \& Figueiredo, A. (2017). What Performance Analysts Need to Know About Research Trends in Association Football (2012-2016): A Systematic Review. Sports medicine, 1-38. http://dx.doi.org/10.1007/s40279-017-0836-6

Serra-Olivares, J., Clemente, F. M., \& González-Víllora, S. (2016). Tactical expertise assessment in youth football using representative tasks. SpringerPlus, 5(1), 1301. http://d x.doi.org/10.1186/s40064-016-2955-1

Tabchnick, B., \& Fidell, L. (2007). Using multivariate statistics. Boston: Allyin \& Bacon.

Towlson, C., Cobley, S., Wayne Midgley, A., Garrett, A., Parkin, G., and Lovell, R. (2017). Relative Age, Maturation and Physical Biases on Position Allocation in Elite-Youth Soccer. International Journal of Sports Medicine, 38(3), 201-209. http ://dx.doi.org/10.1055/s-0042-119029

Travassos, B., Araújo, D., \& Davids, K. (2018). Is futsal a donor sport for football?: exploiting complementarity for early diversification in talent development. Science and Medicine in Football, 2(1), 66-70. http://dx.doi.org/10.1080/24733938 .2017.1390322

Wilkinson, S., Penney, D., \& Allin, L. (2016). Setting and within-class ability grouping: A survey of practices in physical education. European Physical Education Review, 22(3), 336-354. http://dx.doi.org/10.1177/1356336X156107 84

Williams, A. M., \& Reilly, T. (2000). Talent Identification and Development in Soccer. Journal of Sport Sciences, 18, 657-667. http://dx.doi.org/10.1080/02640410050120041

Woods, C. T., Joyce, C., \& Robertson, S. (2016). What are talent scouts actually identifying? Investigating the physical and technical skill match activity profiles of drafted and nondrafted U18 Australian footballers. Journal of science and medicine in sport, 19(5), 419-423. http://dx.doi.org/10.1016 /j.jsams.2015.04.013

Yiannaki, C., Carling, C., \& Collins, D. (2018). Could futsal hold the key to developing the next generation of youth soccer players?. Science and Medicine in Football, 2(1), 71-74. http:/ /dx.doi.org/10.1080/24733938.2017.1332422

Young, J. A., Symons, C. M., Pain, M. D., Harvey, J. T., Eime, R. M., Craike, M. J., \& Payne, W. R. (2015). Role models of Australian female adolescents: A longitudinal study to inform programmes designed to increase physical activity and sport participation. European Physical Education Review, 21(4), 451-466. http://dx.doi.org/10.1177/1356336X155795 74 